\title{
Implementasi Kegiatan Bermain Paperrcrafft dalam Meningkatakan Kemampuan Motorik Halus Anak Kelas B PAUD Taman Sari Banyuasin
}

\author{
Padilah $^{1)}$, Rahmah Novianti ${ }^{2)}$ \\ ${ }^{1}$ Universitas PGRI Palembang \\ email: padilahutama@gmail.com \\ ${ }^{2}$ Universitas PGRI Palembang \\ email: aliciarahmah@gmail.com
}

\begin{abstract}
Abstrak
Penelitian ini adalah Penelitian Tindakan kelas yang bertujuan untuk mendeskripsikan proses Implementasi Kegiatan Bermain Papercraf Dalam Meningkatkan Kemampuan Motorik Halus Anak Usia Dini Di PAUD Taman Sari. Penelitian ini dilakukan pada anak kelas B yang berjumlah 17 orang dengan metode Kemmis dan Taggart yang terdiri dari 4 tahap kegiatan yaitu (rencana, tindakan, observasi dan refleksi). Penelitian ini terdiri dari 2 siklus masing-masing siklus sebanyak 8 pertemuan. Teknik pengumpulan data menggunakan observasi, catatan lapangan, dan dokumentasi. Analisis data menggunakan kuantitatif dan kualitatif. Analisis data kuantitatif dilakukan dengan deskripsi statistik untuk membandingkan pra siklus sampai dengan siklus II. Hasil penelitian menunjukkan terdapat peningkatan kecerdasan interpersonal melalui bermain musik dengan skor pada pra siklus 23,86 meningkat menjadi 35,63 pada siklus I, dan mengalami peningkatan sebesar 42,20 pada siklus II dengan kategori berkembang sangat baik. Ini artinya berdasarkan teori Mills yang menyatakan bahwa kriteria keberhasilan tindakan adalah $71 \%$ dari jumlah anak dapat dikatakan berhasil.
\end{abstract}

Kata Kunci : Bermain, Kemampuan Motorik Halus, Papercraft 


\section{PENDAHULUAN}

Anak usia dini adalah anak dengan rentang usia 0 sampai 6 tahun yang sangat membutuhkan berbagai stimulasi untuk membantu mengembangkan berbagai kemampuan yang dimilikinya. Ada berbagai kemampuan yang dimiliki oleh anak usia dini, salah satunya adalah kemampuan motorik halus anak. Saat ini kemampuan motorik halus yang dimiliki anak masih sering luput dari perhatian para orang tua dan pendidik di lembaga pendidikan anak usia dini.

Sebagian besar fokus lembaga pendidikan anak usia dini hanya untuk mengembangkan kemampuan kognitif yang dimiliki oleh anak saja. Padahal ada berbagai kemampuan lain yang perlu mendapat perhatian oleh orang tua dan guru, yang nantinya dapat membantu anak dikehidupan selanjutnya. Perhatian-perhatian ini dapat berupa stimulasi yang diberikan secara berulang, agar setiap kemampuan anak dapat berkembang secara maksimal.

Kemampuan motorik halus merupakan aktivitas motorik yang melibatkan aktivitas otot-otot kecil yang menuntut koordinasi mata dan tangan serta pengendalian gerak yang memungkinkannya melakukan ketepatan dan kecermatan dalam gerak yang sangat berguna dalam kehidupan sehari-hari. Stimulasi yang baik terhadap kemampuan motorik halus anak sangat penting diberikan, karena akan memberikan dampak positif yang dibutuhkan oleh seorang anak dalam menunjang kemampuan kognitifnya. Misalkan anak dapat mampu menulis, menggunting, menjiplak, mewarnai. melipat, menarik garis dan menggambar.
Sejalan dengan hasil penelitian yang dilakukan oleh Fels, et.al (2015: 697) dengan judul The Relationship Between Motor skills And Cognitive Skills In 4-16 Year Old Typically Developing Children. Hasil penelitiannya menunjukkan bahwa terdapat hubungan antara kemampuan motorik dengan kemampuan kognitif pada anak usia 4-16 tahun.

Hal yang sama dilakukan oleh Julius, et.al (2016: 265) pada penelitian yang berjudul Children's Ability To Learn A Motor Skill Is Related To Handwriting And Reading Proficiency juga menyatakan bahwa terdapat keterkaitan antara pembelajaran motorik anak dengan kemampuan menulis dan membaca anak.

Dari hasil penelitian tersebut, kemampuan motorik sangat penting untuk dikembangkan pada anak untuk membantu kemampuan-kemampuan lainnya terutama pada kemampuan kognitif. Terdapat banyak jenis kegiatan bermain yang dilakukan untuk mengembangkan kemampuan motorik halus pada anak usia dini. Salah satunya yaitu kegiatan bermain papercraft. Papercraft merupakan seni membuat sebuah objek dari bahan dasar kertas, dengan cara menggunting, melipat dan menempel pola yang telah didesain sedemikian rupa agar dapat menjadi bentuk yang kita inginkan. Papercraft ini merupakan pengembangan dari seni origami.

Melihat fakta yang terjadi
dilapangan berdasarkan observasi
yang dilakukan oleh peneliti pada anak
kelompok B di PAUD Taman Sari I
Banyuasin, terlihat bahwa kegiatan di
sekolah masih terlalu berfokus pada
pengembangan kemampuan kognitif
anak saja khususnya pada calistung.
Hal ini didukung oleh tuntutan


orangtua yang sangat ingin anaknya pandai dalam calistung, agar memudahkan si anak untuk memasuki sekolah dasar nantinya. Selain itu pemahaman guru dirasa kurang mengenai pentingnya stimulasi berupa kegiatan yang dapat dilakukan untuk memaksimalkan kemampuan motorik halus yang dimiliki oleh anak. Kegiatan yang diberikan untuk merangsang kemampuan motorik halus anak masih sangat terbatas. Kegiatan yang selama ini dilakukan untuk mengembangkan kemampuan motorik halus hanya sebatas melipat, menggunting dan menempel sesuai dengan petunjuk guru. Mengacu pada penelitian terdahulu yang pernah dilakukan mengenai papercraft. Peneliti tertarik untuk mengaplikasikan kegiatan bermain papercraft pada anak kelompok B PAUD Taman Sari I Banyuasin

\section{Kemampuan Motorik Halus}

Kemampuan motorik halus merupakan salah satu kemampuan yang dimiliki anak dan sangat penting untuk dikembangkan dari berbagai aktivitas kehidupan sehari-hari. Untuk itu kemampuan motorik halus adalah salah satu kemampuan dari aspek perkembangan anak yang perlu dikembangkan.

Luo, et al. (2007: 596) define fine motor skill as "small muscle movements requiring close eye-hand coordination". Yang diartikan bahwa kemampuan motorik halus adalah gerakan otot kecil membutuhkan koordinasi mata-tangan yang erat. Gerakan otot kecil inilah yang nantinya mampu mengembangkan gerakan seperti meremas kertas, melipat, menyobek, melipat, menggambar, menulis dan lain-lain.

Magill (2011:4) mengungkapkan keterampilan motorik halus sebagai sebuah gerakan yang memerlukan kontrol otot-otot ukuran kecil untuk mencapai tujuan tertentu yang meliputi koordinasi mata tangan dan gerakan yang membutuhkan gerakan tangan atau jari untuk pekerjaan dengan ketelitian tinggi. Sejalan dengan pendapat di atas, Papalia (2009:327) menyatakan bahwa keterampilan motorik halus adalah kemampuankemampuan fisik yang melibatkan otot halus serta koordinasi mata tangan.

Dari beberapa pendapat para ahli di atas, dapat disintesiskan bahwa keterampilan motorik halus adalah kemampuan fisik berupa gerakangerakan otot kecil yang membutuhkan koordinasi mata dan tangan untuk mencapai tujuan tertentu. Kemampuan motorik halus anak usia dini pada penelitian ini berfokus pada meniru bentuk, menggunting sesuai dengan pola dan menempel pada gambar yang tepat, sesuai dengan permendikbud Nomor 137 Tahun 2014 Tentang Standar Nasional Pendidikan Anak Usia Dini.

\section{Kegiatan Bermain Papercraft}

Pembelajaran anak usia dini menganut pendekatan bermain sambil belajar atau belajar sambil bermain. Dengan bermain anak menyerap berbagai hal baru disekitarnya. Catron dan Alen dalam Sujiono (2010:35) mengungkapkan bahwa bermain dapat memberikan pengaruh secara langsung terhadap semua area perkembangan anak. Pada saat kegiatan bermain berlangsung hampir semua aspek perkembangan anak dapat terstimulus dan berkembang dengan baik. Salah satu kegiatan bermain yang dapat mempengaruhi perkembangan anak, khususnya kemampuan motorik halus anak adalah papercraft. MenurutSaputra (2013) papercraft adalah seni merakit kertas dari beberapa lembar kertas menggunakan 
beberapa teknik tradisional seperti menggunting, melipat, mengelem, dan membentuk kertas.

Sejalan dengan pendapat Nurjannah (2018: 10) yang menyatakan bahwa papercraft adalah salah satu kerajinan tangan yang berkaitan dengan buatan tangan atau kegiatan yang berkaitan dengan barang yang dihasilkan melalui keterampilan tangan (kerajinan tangan). Janes (2006) mendefinisikan papercraft sebagai kerajinan tangan yang sebagian besar dilakukan dengan kegiatan memotong kertas.

Dari beberapa pendapat di atas, dapat ditarik kesimpulan bahwa kegiatan bermain papercraft adalah salah satu kegiatan seni merakit beberapa lembar kertas dengan menggunakan beberapa teknik tertentu untuk menghasilkan berbagai bentuk yang diinginkan. Bebrapa teknik yang digunakan dalam membuat suatu bentu pada kegiatan ini yaitu, menggunting, melipat dan menempel.

\section{METODE}

Penelitian ini dilaksanakan di PAUD Taman Sari I pada Kelompok B Kecamatan Talang Kelapa Kabupaten Banyuasin. Waktu penelitian adalah selama satu tahun, yang direncanakan akan berjalan mulai bulan Aagustus 2018 sampai dengan Juli 2019.

\section{Metode Penelitian}

1. Metode Tindakan

Metode penelitian yang digunakan adalah metode action research atau penelitian tindakan yang dilakukan dalam bentuk spiral. Penelitian tindakan ini dilakukan sebagai perbaikan suatu praktek pendidikan melalui pemberian

pendidikan berdasarkan refleksi dari pemberian tindakan.

2. Desain Tindakan

Desain penelitian yang digunakan dalam penelitian ini yaitu model dari Kemmis dan Taggar berupa suatu siklus spiral. Handini (2012:19) mengungkapkan tahap-tahap rancangan pada setiap utarannya adalah sebagai berikut: (a) perencanaan (planning); (b) tindakan (acting); (c) observasi (observation); (d) refleksi (reflection).

\section{Prosedur Penelitian Tindakan}

1. Kegiatan Pra Penelitian

Kegiatan ini dilaksanakan sebelum siklus pertama dilakukan. Pada kegiatan ini peneliti melakukan wawancara dengan Kepala Sekolah dan guru. Peneliti mengamati RPPH yang dibuat dan proses belajar mengajar yang selama ini diterapkan. Peneliti melakukan diskusi dengan guru untuk membahas pemecahan masalah yang terjadi dalam kelas dan membahas program kegiatan yang akan dilakukan untuk mengatasi permasalahan tersebut.

2. Pelaksanaan Siklus I

Siklus pertama ini direncanakan dilakukan dalam delapan kali pertemuan. Setiap pertemuan siklus dilakukan melalui empat tahap yaitu: perencanaan, tindakan, pengamatan dan refleksi.

a. Perencanaan Siklus I

Tahap perencanaan ini terdiri dari empat kegiatan, yaitu: (1) menentukan target kompetensi; 
mendesain pembelajaran pada beberapa siklus; (3) mendesain lembar observasi. Rancangan pelaksanaan

pembelajaran untuk meningkatkan

kemampuan motorik halus melalui penerapan kegiatan bermain papercraft.

b. Pelaksanaan Siklus I

Dalam setiap tahapan pelaksanaan

pembelajaran yang diterapkan berdasarkan pada langkah pembelajaran yang telah dibuat. Pelaksanaan tindakan ini dilaksanakan secara berulang dan dilakukan selama delapan kali pertemuan.

c. Pengamatan Siklus I

Tahap pengamatan dilakukan untuk mengamati kemampuan motorik halus anak pada setiap tindakan yang diberikan. Pada tahap ini, peneliti dan tim kolabolator mengamati dengan menggunakan lembar observasi dan isntrumen pemantau tindakan guru dan anak didik.

d. Refleksi Siklus I

Pada tahap akhir, dilakukan dengan membuat refleksi dan kesimpulan yang telah dilakukan. Tahp ini dilakukan setelah pelaksanaan tindakan. Peneliti dan tim kolaborator merefleksikan tindakan

$$
\begin{array}{lr}
\text { yang telah dilakukan, } \\
\text { mendiskusikan } & \text { dan } \\
\text { melakukan } & \text { evaluasi } \\
\text { berdasarkan } & \text { hasil } \\
\text { tindakan, r serta } \\
\text { pengamatan. } & \text { Apabila } \\
\text { hasilnya belum } & \text { sesuai } \\
\text { dengan hasil yang } & \text { yana } \\
\text { diharapkan, maka harus } \\
\text { disipakan langkah- } \\
\text { langkah perbaikan untuk } \\
\text { perencanaan bagi siklus } \\
\text { berikutnya. }
\end{array}
$$

3. Pelaksanaan Siklus II

Siklus II dilaksanakan dengan melakukan perubahan pada bagian-bagian tertentu yang didasarkan pada refleksi siklus I, sesuai dengan RPPH yang telah dibuat. Sasaran kegiatan adalah untuk memperbaiki aspek-aspek yang dinilai belum berhasil pada siklus I. Langkah yang digunakan sama halnya dengan yang dilakukan pada siklus I.

\section{Kriteria Keberhasilan Tindakan}

Untuk mengukur kemampuan motorik halus anak, penelitian ini menggunakan Kriteria Keberhasilan Minimal (KKM) sebesar $75 \%$ dan Kriteria Keberhasilan Tindakan (KKT) sebesar $71 \%$.

\section{Data dan Sumber Data}

Data hasil penelitian pada penelitian ini adalah data kemampuan motorik halus anak pada kelompok B PAUD Taman Sari I. Sumber data penelitian ini adalah seluruh anak kelompok B PAUD Taman Sari I yang berjumlah 17 anak..

\section{Teknik Pengumpulan Data}

Teknik pengumpulan data diperoleh dari lembar observasi 
kemampuan motorik halus anak; wawancara dan dokumentasi.

\section{Teknik Analisis Data}

Teknik analisi data yang dilakukan dalam penelitian ini melalui teknik analisis kualitatif dan teknik analisis kuantitatif. Teknik analisi data kualitatif menggunakan teknik analisis interaktif yang dikembangkan oleh Miles dan Huberman. Teknik analisi

kuantitatif dilakukan dengan rumus $\mathrm{P}=\frac{f}{N} \times 100 \%$.

\section{HASIL DAN PEMBAHASAN}

Adapun penelitian yang relevan dengan penelitian ini yaitu penelitian yang dilakukan oleh Suggate, et al. (2016) dengan judul penelitian Relations Between Playing Activities And Fine Motor Development. Hasil penelitiannya menunjukkan bahwa terdapat hubungan antara kegiatan bermain dengan perkembangan motorik halus anak. Perbedaan dengan penelitian yang dilakukan adalah peneliti menfokuskan kegiatan bermain yaitu dengan bermian papercraft untuk meningkatkan kemampuan motorik halus pada anak usia dini.

Selanjutnya penelitian yang dilakukan oleh Nurjannah (2018) dengan judul penelitian Peningkatan Kemampuan Motorik Halus Anak Kelompok A Melalui Kegiatan Bermain Papercraft. Hasil penelitian yang dilakukan selama dua siklus pengamatan perkembangan kemampuan motorik halus anak kelompok A mengalami peningkatan pada setiap siklusnya. Pengamatan sebelum tindakan (pra siklus) sebesar
$34 \%$, pada siklus I sebesar $60,6 \%$ dengan peningkatan $26,6 \%$ dan pada siklus II sebesar $83,82 \%$ dengan peningkatan sebesar $23,22 \%$. Dengan demikian presentase peningkatan kemampuan motorik halus anak kelompok A melalui kegiatan papercraft telah mencapai indikator keberhasilan yaitu lebih dari $75 \%$. Artinya kegiatan bermain papercraft sangat efektif dan dapat digunakan dalam meningkatkan kemampuan motorik halus anak kelompok A. Dari hasil penelitian di atas, peneliti tertarik untuk menerapkan kegiatan bermain papercraft untuk meningkatkan kemampuan motorik halus anak usia dini. Pada penelitia yang dilakukan peneliti, peneliti akan menerapkan kegiatan bermain papercraft pada kelompok B di PAUD Taman Sari I Banyuasin

Berdasarkan analisis yang telah dilakukan secara kualitatif dan kuantitatif, pada catatan lapangan, observasi, dan catatan dokumentasi maka hasilnya terdapat peningkatan Motorik Halus anak melalui Kegiatan Bermain Papercraft. Anak - anak mengalami peningkatan Motorik Halus pada indikator:

- Anak mampu pada kemampuan motorik halus yaitu kemampuan anak meniru bentuk dengan kertas

- Anak mampu pada kemampuan motorik halus yaitu kemampuan anak menggunting sesuai pola

- Anak mampu pada kemampuan motorik halus yaitu kemampuan anak menempel gambar dengan tepat 


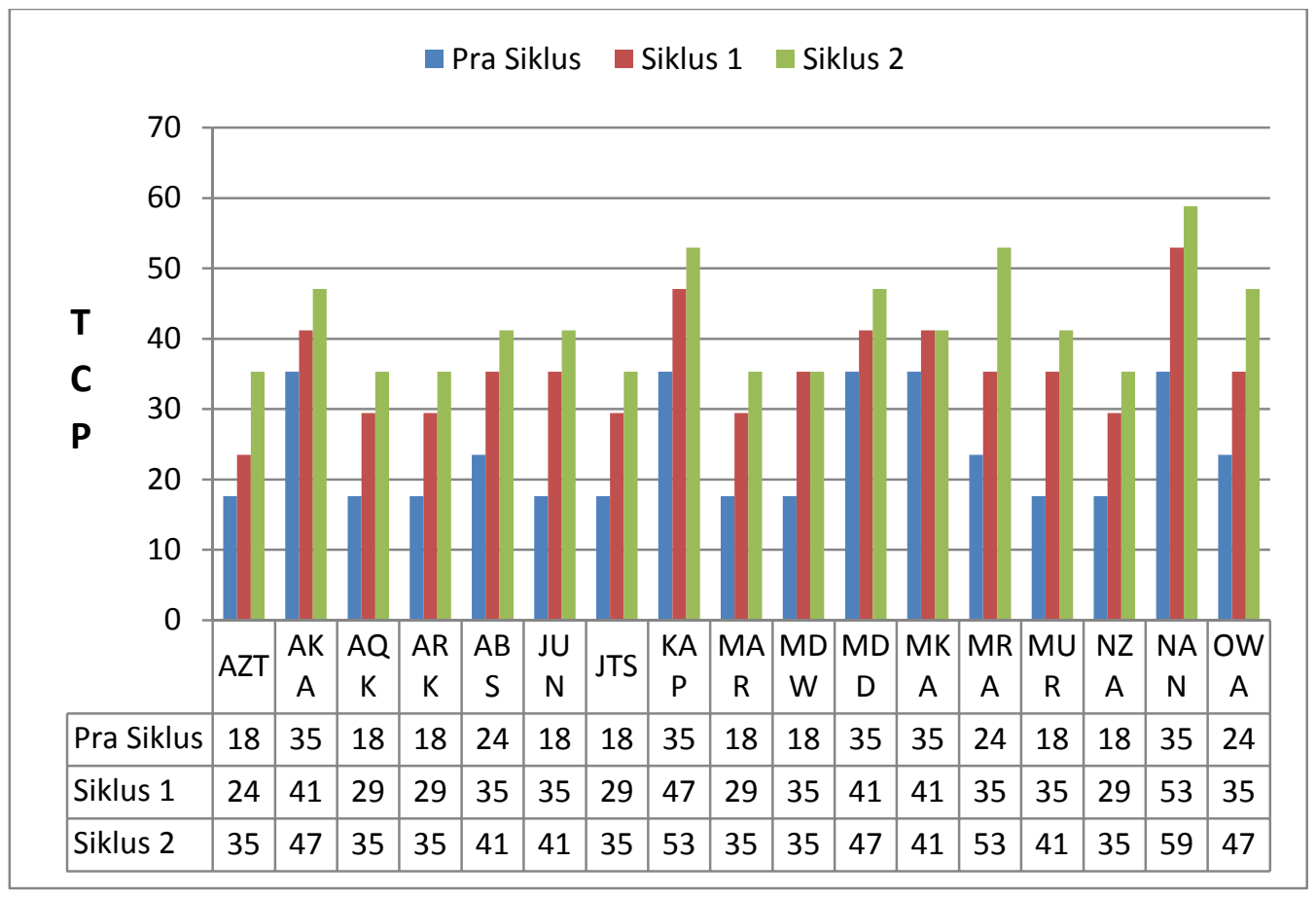

Grafik Hasil Tingkat Capaian Perkembangan KemampuanMotorikHalusAnakKelas B PAUD Taman Sari Banyuasin

Pada Pra Siklus, Siklus I Dan Siklus 2

Tabel Data Peningkatan Kemampuan Motorik Halus Anak Kelas B Di PAUD Taman Sari Banyuasin

\begin{tabular}{|c|c|c|c|}
\hline Skor Tahapan & Pra Siklus & Siklus I & Siklus II \\
\hline Rata-rata & 23,86 & 35,63 & 42,20 \\
\hline Peningkatan & - & 11,77 & 6,57 \\
\hline
\end{tabular}


Dari grafik dan tabel di atas dapat kita lihat bagaimana peningkatan kemampuan motorik halus anak meningkat dari pra siklus, siklus I dan siklus II. Pada siklus II rata-rata tingkat capaian perkembangan (TCP) anak telah mencapai kriteria keberhasilan yang ditentukan oleh peneliti dan kolaborator, sehingga penelitian tindakan ini dikatakan telah berhasil.

Berdasarkan hasil penelitian data ini menunjukan bahwa kemampuan motorik halus anak meningkat, hal ini terlihat dari grafik dan tabel $71 \%$ dari jumlah anak berada pada kategori BSB( BerkembangSangatBaik). 71\% artinya 14 dari 17 anak beradadalamkategori BSB (BerkembangSangatBaik).

\section{KESIMPULAN}

Berdasarkan hasil pembahasan penelitian diatas, kegiatan bermain papercraft memang dapat meningkatkan motorik halus anak usia dini, hal ini sesuai yang dikemukan oleh Nurjannah (2018) dengan judul penelitian Peningkatan Kemampuan Motorik Halus Anak Kelompok A Melalui Kegiatan Bermain Papercraft. Hasil penelitian yang dilakukan selama dua siklus pengamatan perkembangan kemampuan motorik halus anak kelompok A mengalami peningkatan pada setiap siklusnya. Pengamatan sebelum tindakan (pra siklus) sebesar $34 \%$, pada siklus I sebesar $60,6 \%$ dengan peningkatan $26,6 \%$ dan pada siklus II sebesar $83,82 \%$ dengan peningkatan sebesar 23,22\%. Dengan demikian presentase peningkatan kemampuan motorik halus anak kelompok A melalui kegiatan papercraft telah mencapai indikator keberhasilan yaitu lebih dari $75 \%$. Artinya kegiatan bermain papercraft sangat efektif dan dapat digunakan dalam meningkatkan kemampuan motorik halus anak kelompok A

\section{DAFTAR PUSTAKA}

[1] Fels, et. al. 2015. The Relationship Between motor Skill And Cognitive Skill In 4-6 Year Old Typically Development Children. Journal of Science and Medicine in Sport. November 2015, Volume 18, Issue 6.

[2] Handini, Myrnawati Cri. 2012. Metodologi Penelitian Untuk PemulaI. Jakarta: FIP Press

[3] Janes, Susan Niner. 2006. Creative Craft You Can Do in a Day. North Light Books.

[4] Juliys, et. al. 2016. Children's Ability To Learn A Motor Skill Is Related To Handwriting And Reading Proficiency. Learning and Individual Defferences. October 2016, Volume 51.

[5] Magill, Richard A. 2011. Motor Learning, Concepts And Application. Boston: Mc. Graw Hill.

[6] Nurjannah, Dwi. 2018. Peningkatan Kemmapuan Motorik Halus Anak Kelompok A Melalui Kegiatan Bermain Papercraft. Jurnal AUDI: Jurnal Ilmiah Kajian Ilmu Anak dan Media Informasi PAUD, Volume 3, Nomor 1.

[7] Papalia, Diana E, dkk. 2009. Human Development : Perkembangan Manusai Edisi ke 10. Jakarta: Salemba Humanika.

[8] Saputra, Yosan Darma. 2013. Perancangan Visiualisasi Papercrfat Wayang Golek Jawa Barat Sebagai Edukasi dan Entertaiment Untuk Anak-Anak. Undergraduate Thesis, Universitas Kristen Maranatha.

[9] Suggate, Sebastian, et.al. 2016. Relationship Between Playing 
Activities And Fine Motor

Development. Early Child

Development And Care, Volume

187 , Isuuse 8.

[10] Sujiono, Bambang, dkk. 2010.

Metode Pengembangan Fisik.

Jakarta: Universitas Terbuka. 